\title{
Pixel based Classification of Poultry Farm using Satellite Images
}

\section{Roshini M, V Poompavai, K Ganesha Raj}

\begin{abstract}
Remote sensing has emerged as a compelling tool to survey and monitor natural resources and other features of an area due to the inherent advantages of synoptic view, repetitive nature and capability to study inaccessible areas. Satellite data/aerial photos are interpreted using keys such as colour/tone, texture, pattern, association, size, shape, etc., and computer-based techniques. Presently geospatial technology is used in various sectors like agriculture, forestry, geology, marine, urban and rural planning and so on, with applications in agriculture seeing a rise in India. This paper elaborates on the method employed for identification of poultry farms in India, using images from satellites such as CARTOSAT and RESOURCESAT (LISS4) and also Google Earth Images. Each poultry farm varies in the size and number of poultry sheds which further depend on the number of chickens bred, location of vegetation and water resources nearby, temperature and humidity of location, etc. Thus, based on these factors, training sites in Hessarghatta, Harohalli, Dommasandra near Bengaluru City, Karnataka were identified. The paper elucidates application of vegetation and water masks using the classification of NDVI. Two pixel-based classification techniques - Maximum Likelihood Classifier and K-Nearest Neighbour Classifier using SNAP Application were applied. Statistics were observed for the accuracy of classified output, and it was shown that Maximum Likelihood Classifier provided more accurate results. The method presented in this paper can be fine-tuned and applied for poultry farms anywhere by studying Poultry Farms in different terrains and using various associations to identify them.
\end{abstract}

Index Terms - Remote Sensing, Poultry Farms, Pixel Based Classification

\section{INTRODUCTION}

\section{A. Remote Sensing in Agriculture Sector in India}

Remote sensing is obtaining information about objects and areas from satellites, aerial sensors, drones, etc. Thus, remote sensing along with complementary technology such as Geographical Information System (GIS), Geographical Positioning System (GPS), Information and Communication Technologies the assessment, of various natural resources and features mapping and monitoring has become more versatile. In the recent years however, geospatial technologies have been extensively used in the agriculture sector. One such application has been dealt with in this paper.

India's poultry industry has undergone a fundamental change in structure and operation. The success of the poultry farming business depends on construction and management of suitable poultry housing.
Therefore, construction of poultry houses needs to be done by taking into account a lot of details such as size of houses, material to be used in construction, surrounding vegetation, environmental conditions around poultry farm, etc. Satellite Imagery can be used to identify poultry sheds by considering the various factors mentioned. Landsat satellites analyse the greenness of vegetation using indices like Normalized Difference Vegetation Index (NDVI). Thus, for this project, CARTOSAT and RESOURCESAT(LISS4) sensor imagery has been used. In this paper, creation of vegetation and water masks with the calculation of NDVI has been expounded. Poultry Farms/sheds were identified using Pixel based Classification Methods: Maximum Likelihood Classifier and K-Nearest Neighbour. The statistics were derived and after comparison of the results from the two methods, the ideal classification method was identified based on accuracy.

\section{B. Attributes and Features of Poultry Farms}

In the "Poultry Farm and Manual Reference guide for central and state poultry farms 2014-15" document released by Department of Animal Husbandry, Dairying and Fisheries, Ministry of Agriculture and Farmers Welfare, Government of India [1], infrastructure plan has been covered. It has been instructed that the farm shall not be located at least 100 meters from any major water drinking source hence by observing water bodies, or by creating water masks, poultry houses can be identified. It has also been mentioned that the farm shall raise green belt all round with minimum of two rows spaced apart of not more than 3 meters, hence creating NDVI masks and observing the vegetation and the distance of the buildings around it, it is made easier to identify poultry farms.

In the document "Facilitator Guide- Small Poultry Farmer" by Agriculture Skill Council of India [2], the preparation and maintenance of accommodation for poultry birds has been explained. Constructing sheds such that the long axis end walls orient towards the East-West direction and the side walls face the North-South direction is advised. Thus, after referring to various sites, documents and papers a collection of the various attributes of a poultry farm was tabulated in Table 1.

Table 1: Various attributes of Poultry Sheds and Farms:

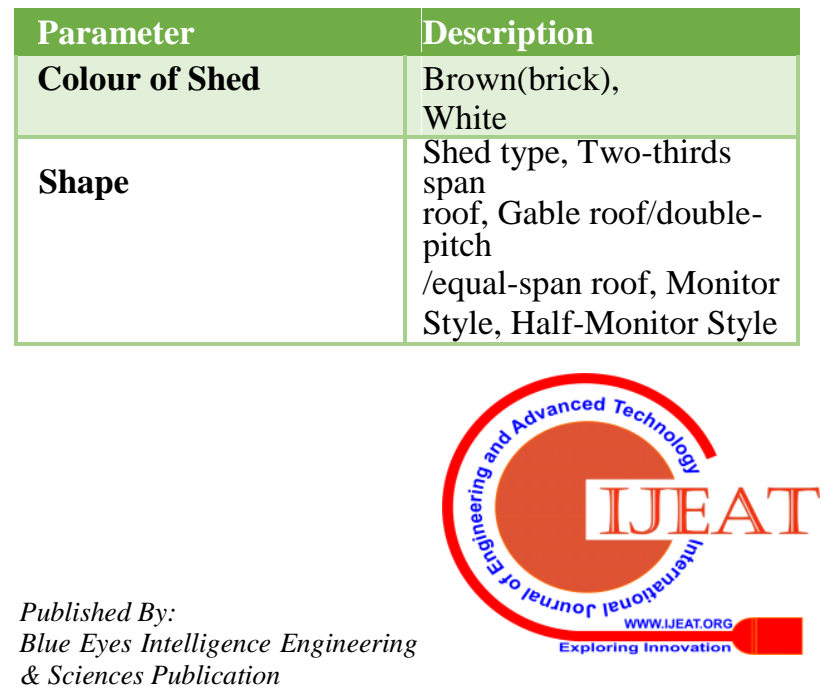

Revised Manuscript Received on December 15, 2019.

Roshini M, Electronics and Communication Engineering, PES University- RR Campus, Bengaluru, Karnataka 560085.

Dr V Poompavai, RRSC- South, NRSC, ISRO Marathahalli, Bengaluru, Karnataka 560037.

Dr K Ganesha Raj, RRSC- South, NRSC, ISRO Marathahalli, Bengaluru, Karnataka 56003 


\begin{tabular}{|c|c|}
\hline Length & $\begin{array}{l}\text { Depends on Number of } \\
\text { birds } \\
\text { reared }\end{array}$ \\
\hline Width & $\begin{array}{l}22-25 \text { feet (tropical } \\
\text { Countries) } \\
25-40 \text { feet (ridge } \\
\text { ventilation at } \\
\text { the middle line of the roof } \\
\text { top } \\
\text { with proper overhang is a } \\
\text { must) } \\
>40 \text { feet (environmentally } \\
\text { controlled poultry houses, } \\
\text { i.e. } \\
\text { controlled with the help of } \\
\text { exhaust fans) }\end{array}$ \\
\hline Height & $\begin{array}{l}\text { 6-7 feet(side) } \\
10-12 \text { feet(centre) }\end{array}$ \\
\hline Foundation & $\begin{array}{l}\text { Concrete with } 1 \text { to } 1.5 \text { feet } \\
\text { below the surface and } 1 \text { to } \\
1.5 \\
\text { feet above the ground } \\
\text { level }\end{array}$ \\
\hline Roof & $\begin{array}{l}\text { The roof of the poultry } \\
\text { house } \\
\text { may be thatched, tiled, } \\
\text { asbestos } \\
\text { or concrete one } \\
\text { depending } \\
\text { upon the cost } \\
\text { involvement. } \\
\text { Gable type Roof is most } \\
\text { preferred in India. }\end{array}$ \\
\hline Overhang of Roof & $>3.5$ feet \\
\hline Temperature & $22-30 \mathrm{C}(70-85 \mathrm{~F})$ \\
\hline Relative Humidity & $30-60 \%$ \\
\hline Ammonia Level & Less than $25 \mathrm{ppm}$ \\
\hline $\begin{array}{l}\text { Spacing between two } \\
\text { sheds }\end{array}$ & $34-45$ feet $(0.4 \times \mathrm{H} \sqrt{ } \mathrm{L})$ \\
\hline Door size & $6 \times 2.5$ feet \\
\hline $\begin{array}{l}\text { Type of Poultry } \\
\text { Housing } \\
\text { System based on } \\
\text { Availability of land, } \\
\text { Cost of } \\
\text { land, Type of farming } \\
\text { activity, Climatic } \\
\text { condition } \\
\text { and } \\
\text { Labour availability }\end{array}$ & $\begin{array}{l}\text { 1.Free range or extensive } \\
\text { system } \\
\text { 2.Semi-intensive system } \\
\text { 3.Intensive system: } \\
\text { a. Deep-litter system } \\
\text { b. Slatted floor system } \\
\text { c. Slat cum litter system } \\
\text { d. Cage system }\end{array}$ \\
\hline $\begin{array}{l}\text { Type of Poultry } \\
\text { Housing } \\
\text { System based on } \\
\text { breeding }\end{array}$ & $\begin{array}{l}\text { 1.Brooder / chick house } \\
\text { 2.Brooders cum grower } \\
\text { house } \\
\text { 3.Layer house } \\
\text { 4.Breeder house } \\
\text { 5.Environmentally } \\
\text { controlled } \\
\text { (EC) house }\end{array}$ \\
\hline Lighting inside house & $\begin{array}{l}\text { Incandescent lights } \\
\text { Fluorescent tube light } \\
\text { Compact Fluorescent light }\end{array}$ \\
\hline $\begin{array}{l}\text { Emissions from Poultry } \\
\text { Houses }\end{array}$ & $\begin{array}{l}\text { carbon dioxide }(\mathrm{CO} 2), \\
\text { nitrous } \\
\text { oxide }(\mathrm{N} 2 \mathrm{O}), \text { and } \\
\text { methane } \\
(\mathrm{CH} 4), \text { Ammonia }(\mathrm{NH} 3)\end{array}$ \\
\hline
\end{tabular}

\begin{tabular}{|c|c|}
\hline Selection of Location & $\begin{array}{l}\text { 1.Poultry houses should } \\
\text { not be } \\
\text { located near residential or } \\
\text { industrial areas. } \\
\text { 2.It should have proper } \\
\text { road } \\
\text { facilities. } \\
\text { 3.It should have the basic } \\
\text { amenities like water and } \\
\text { electricity. } \\
\text { 5. Elevated areas where } \\
\text { there is } \\
\text { no water logging is best } \\
\text { suited } \\
\text { for poultry houses. } \\
\text { 6.It should have proper } \\
\text { ventilation. } \\
\text { 7. Away from Wildlife }\end{array}$ \\
\hline Housing Direction & $\begin{array}{l}\text { North-East to South } \\
\text { West } \\
\text { Direction (Hot and Cold } \\
\text { Climate) } \\
\text { North-South Direction } \\
\text { (Cold } \\
\text { Climate) } \\
\text { East-West Direction (Hot } \\
\text { Climate) }\end{array}$ \\
\hline $\begin{array}{l}\text { Vegetation/Trees Around } \\
\text { Poultry Farms }\end{array}$ & $\begin{array}{l}\text { Trees enhance air quality } \\
\text { by } \\
\text { cutting nuisance } \\
\text { emissions of } \\
\text { dust and Ammonia and } \\
\text { improve water quality by } \\
\text { filtering pollutants from } \\
\text { soil } \\
\text { and groundwater. }\end{array}$ \\
\hline Water Requirement & $\begin{array}{l}\text { A typical } 500 \text {-ft broiler } \\
\text { house } \\
\text { requires about } 2 \text { gallons } \\
\text { of } \\
\text { water per minute for } \\
\text { drinking } \\
\text { water. } \\
\text { A 5-house complex } \\
\text { would } \\
\text { require about } 20 \text {-gallons } \\
\text { of } \\
\text { water a minute just for } \\
\text { drinking } \\
\text { water for the broilers. } \\
1-2 \text { taps running at } 20 \\
\text { psi / } \\
\text { low pressure will use } 45 \\
\text { litres } \\
\text { of water a minute. }\end{array}$ \\
\hline Water source & $\begin{array}{l}\text { Rain water harvesting, } \\
\text { Water } \\
\text { Storage, Pumps }\end{array}$ \\
\hline
\end{tabular}

\section{Selection of Training Sites}

Based on the factors such as- Colour of Shed, Size and Shape of sheds, spacing between two sheds and selection of location of poultry farms- location of water bodies, vegetation or cultivated land near poultry farms, several training sites were chosen as shown in Fig.1,2 and 3. 
A few examples of the training sites chosen:

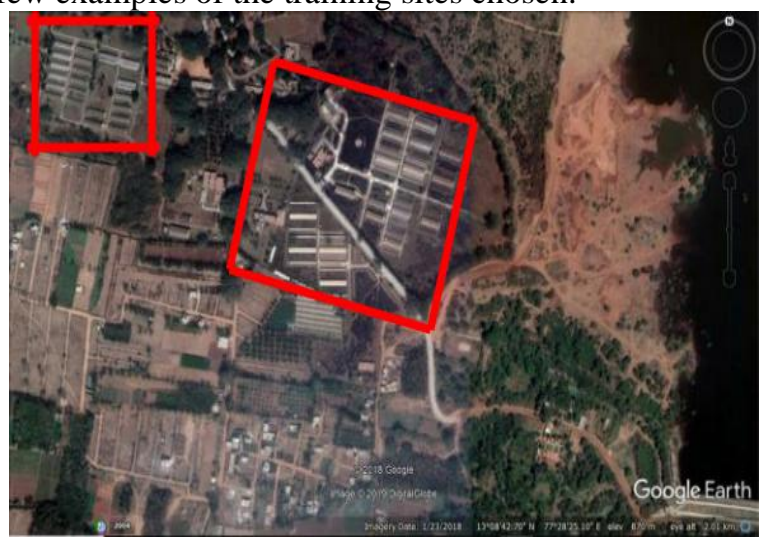

Fig. 1 Poultry Farms near Hessarghatta Lake, Bengaluru, Karnataka obtained from Google Earth Pro

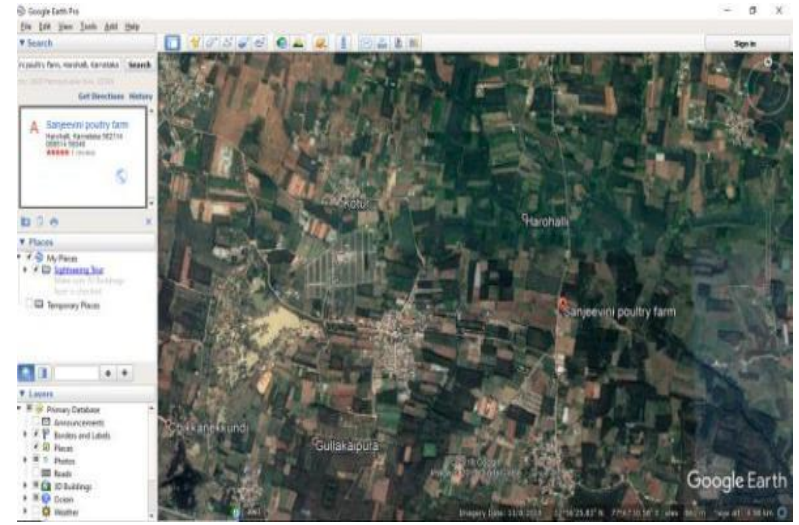

Fig. 2 Image of Poultry Farms near Harohalli, Karnataka obtained from Google Earth Pro

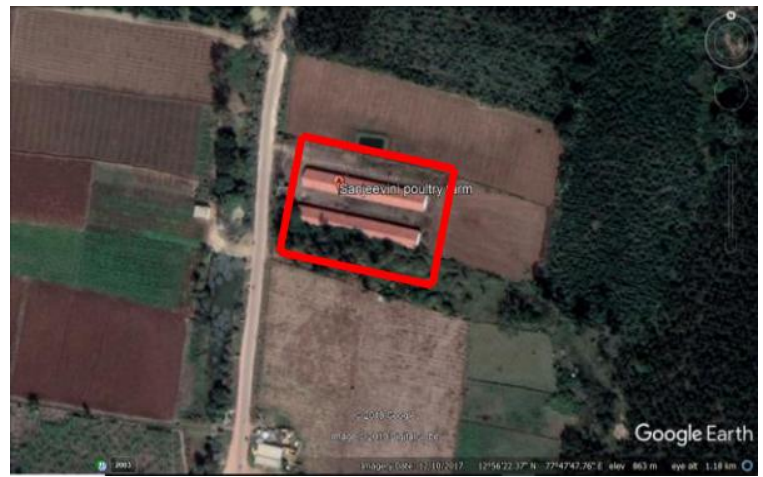

Fig.3 Image of Sanjeevini Poultry Farm in Harohalli, Karnataka obtained from Google Earth Pro

\section{FIELD SURVEY}

Every poultry farm differs in its geographical location, number of chickens bred, type of poultry houses based on breed of chicken, size of poultry house, etc. Hence, field survey was conducted at learn more about the poultry housing. The survey was conducted at Tarikere Taluk, Chikmagaluru District.

AC sheets placed on iron rods, for the shed of the poultry house. During summer, to keep the sheds cool, branches from coconut trees are placed on the roof. Mosquito nets placed on the sides, and tarpaulin sheets are rolled down at night to maintain temperature - around 25-30 deg $\mathrm{C}$ as shown in Fig.4 and Fig.5. The number of chickens bred were 4850 in the shed, shown in Fig. 6. The dimensions of the shed were $200 * \mathbf{2 5} * \mathbf{1 5}$ cube feet. 1000 litres of water and $500 \mathrm{~kg}$ seeds are used to feed birds daily.

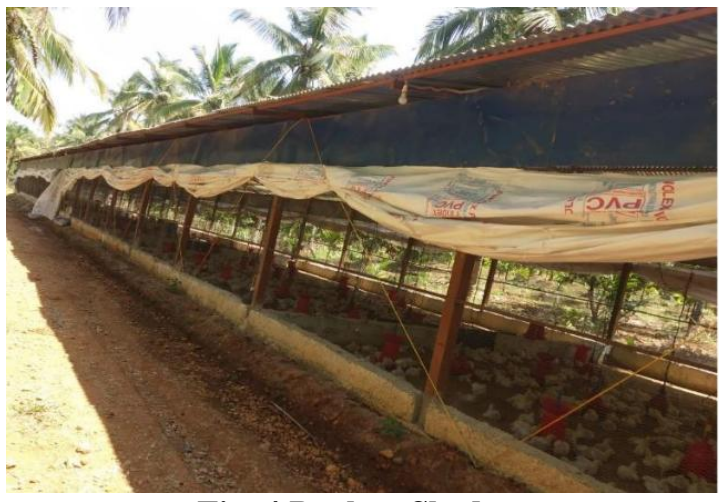

Fig. 4 Poultry Shed

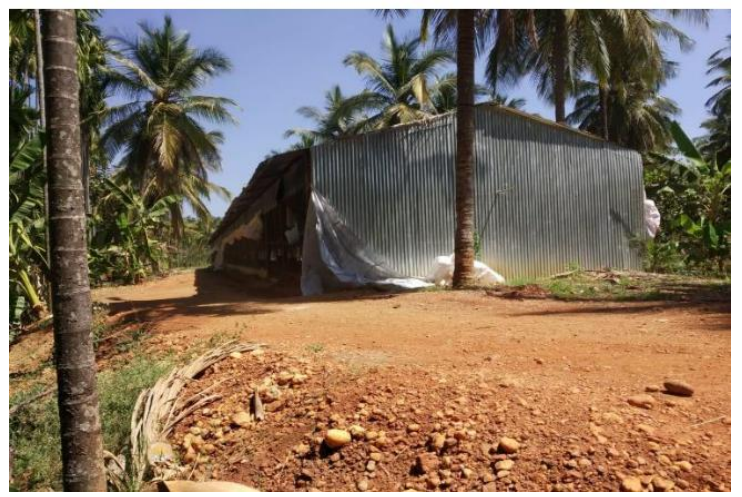

Fig. 5 Back View of Poultry Shed

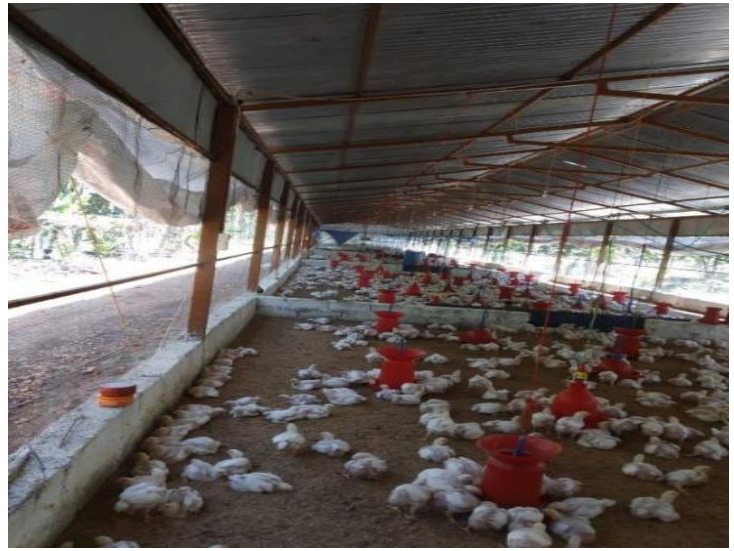

Fig. 6 Chicken breeding inside the Poultry Shed

\section{STUDY AREA}

The tiff used was obtained from CARTOSAT-1 and RESOURCESAT- LISS4 (merged) satellite data. The area contains lot of poultry farms on the far side of Bengaluru, Karnataka, India. The tile uploaded in SNAP (.tif image) was between the coordinates: $12^{\circ} 56^{\prime} 54^{\prime \prime} \mathrm{N}, 77^{\circ} 47^{\prime} 20^{\prime \prime} \mathrm{E}$ ; $12^{\circ} 55^{`} 16^{\prime \prime} \mathrm{N}, 77^{\circ} 46$

$53^{\prime \prime} \mathrm{E} ; 12^{\circ} 55^{`} 36^{\prime \prime} \mathrm{N}, 77^{\circ} 45^{`} 10^{\prime \prime} \mathrm{E} ; 12^{\circ} 57^{`} 06^{\prime \prime} \mathrm{N}, 77^{\circ}$ $45^{\prime} 43^{\prime \prime}$ E. The area covers Horahalli, Dommasandra, Halasahalli, Sorahunase, Kotur, etc, all situated in the state of Karnataka. The Poultry farms that can be identified in the tif file are:

1. Sanjeevini Poultry Farm, Harohalli, Bengaluru, Karnataka.

2. BairappaPoultryFarm,Pate Narayanswamy Layout, Siddapura, Whitefield,

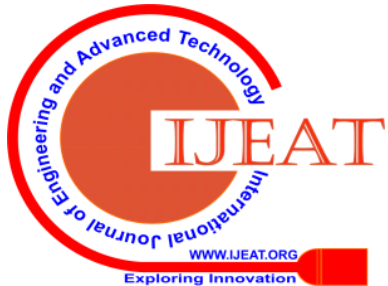


Bengaluru, Karnataka

3. Seenappa KM and Kamalesh Poultry Farm, Kotur Village, Muthsandra, Post, Bengaluru, Karnataka

4. Kanaga Poultry Service, 67, Lalbagh Fort Rd, Doddamavalli, Sudhama Nagar, Bengaluru, Karnataka 560004

5. Muneshwara Poultry Farm, Volagerekallahalli, Karnataka

6. Rishi Poultry Farm, Dommasandra, Bengaluru, Karnataka

\section{METHODOLOGY}

\section{A. Flowchart}

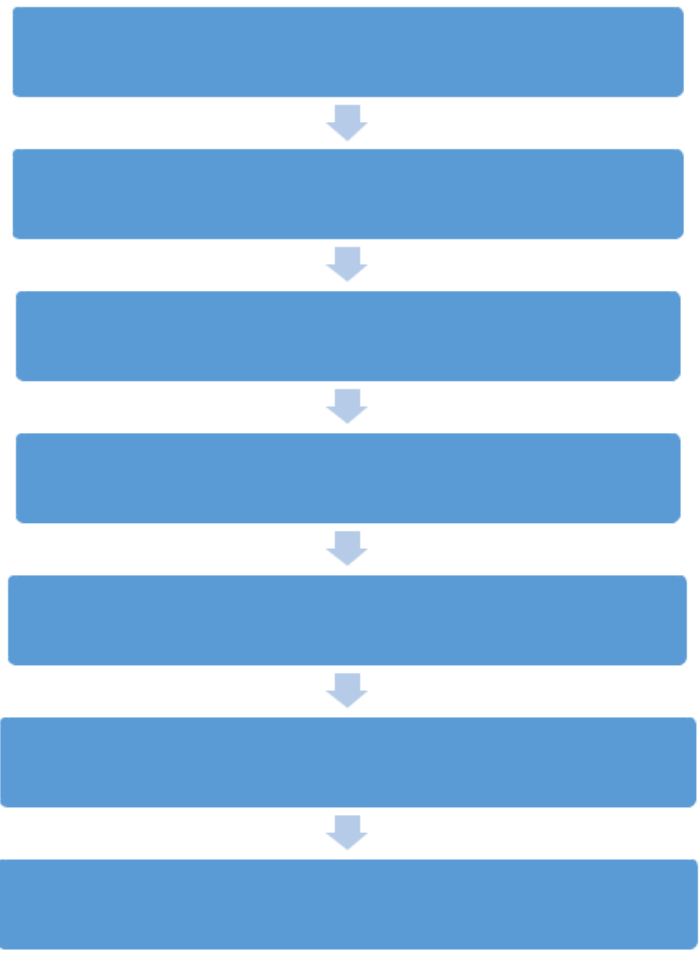

\section{B. Creating Vector Data Sets and Masks}

The product is opened in SNAP software, and opened as an RBG Image Window. New vector data containers were created: Vegetation, cultivated land, Water, Poultry Farms, Other buildings, as shown in Fig. 7.

The colour scheme for various vector data sets has been mentioned in Fig. 8.

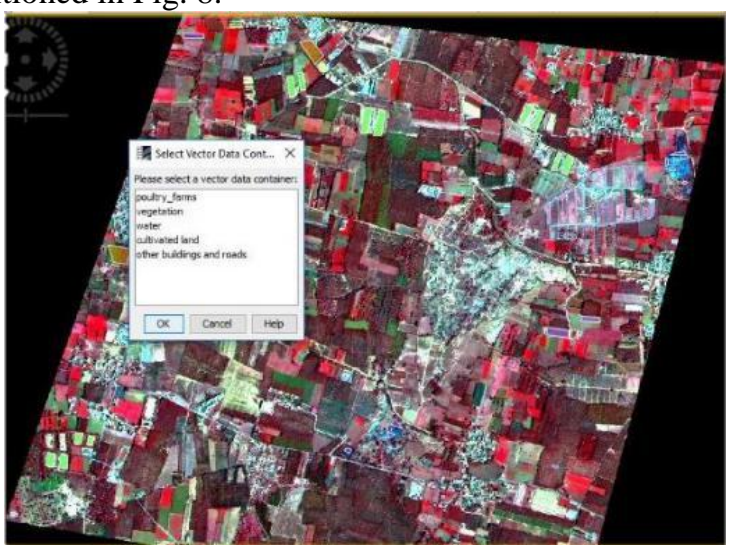

Fig. 7 Creating and assigning vector Data Sets

\begin{tabular}{|l|l|}
\hline Vector Data Set created & Colour \\
\hline Vegetation & \\
\hline Cultivated Land & \\
\hline Water & \\
\hline Poultry Farms & \\
\hline Other Buildings & \\
\hline
\end{tabular}

Fig. 8 Colour map of vector data sets

A new band - "NDVI_band" was creating using the NDVI formula in (1) using Band Maths.

$($ NIR- RED $) /($ NIR+RED $)=($ band_1 - band_2 $) /$

(band_1 + band_2)

A mask for water and vegetation was then created by entering the threshold for water and vegetation, using (2)

NDVI_band $<0$ or NDVI_band $>0.2$,

Where, Pixels with value $<0$ were extracted as water bodies and pixels with value $<0.2$ were extracted as vegetation.

The resulting mask, containing both water and vegetation has been represented in Fig 9.

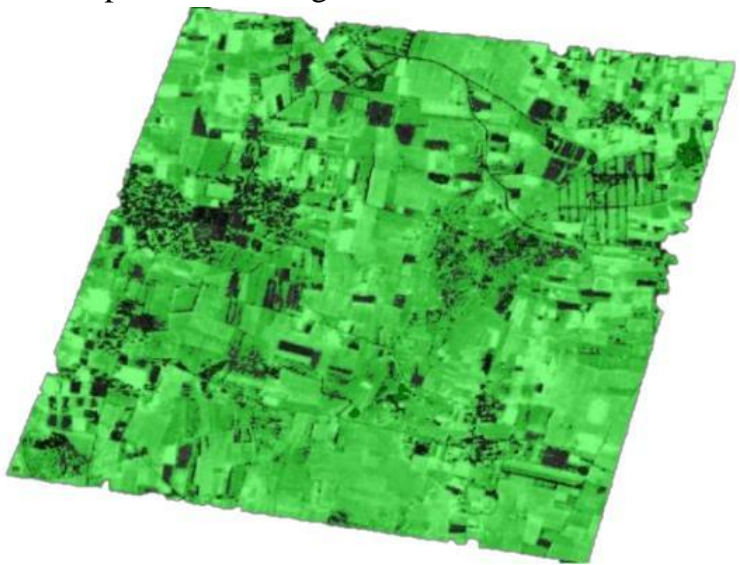

Fig. 9 NDVI_band: Water and Vegetation Region has been shown in green.

After the masking of water bodies and vegetation, two classes were created: Poultry Farms and other buildings as displayed in Fig. 10

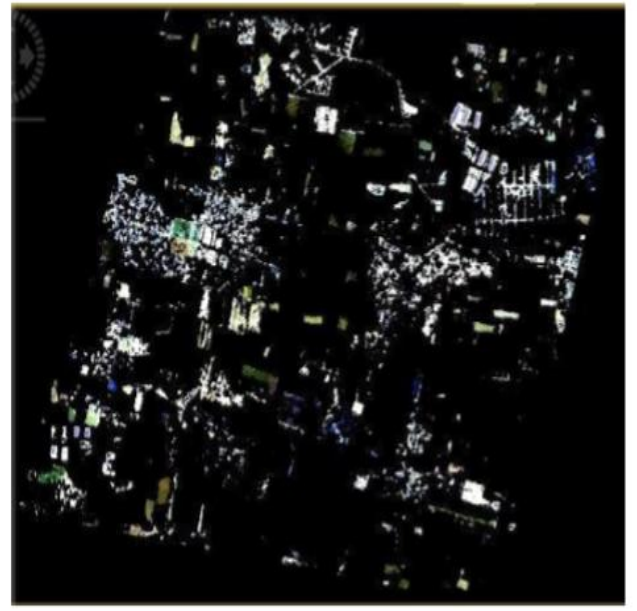

Fig. 10 After masking of water bodies and vegetation, and creating classes

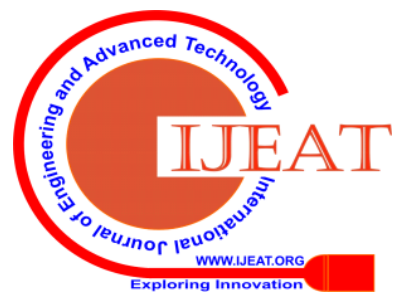




\section{Supervised Classification}

\section{1)Maximum Likelihood Classifier:}

The ML Classifier outputs highlighted the poultry farms in yellow and other buildings in purple while masking out the vegetation and water as shown in Fig. 11 and colour scheme represented in Fig. 12.

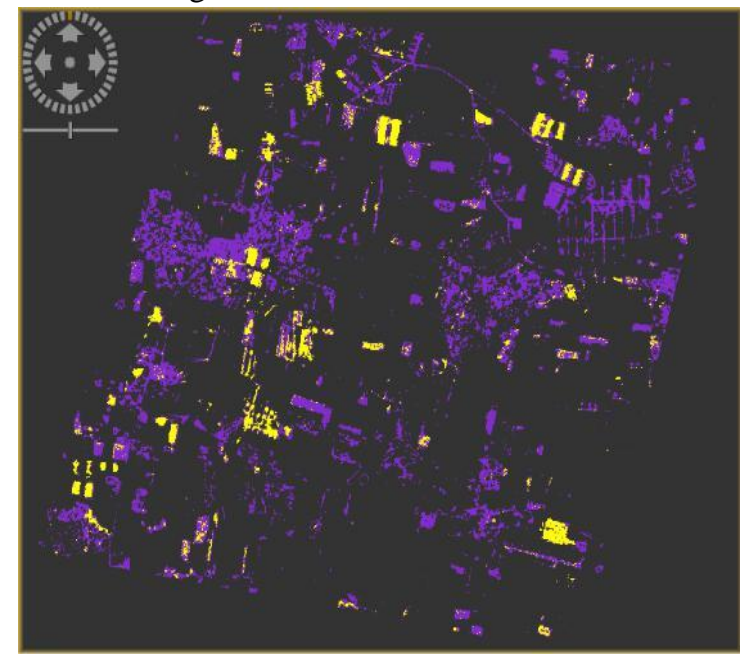

Fig. 11 Classification of Poultry Farms and other buildings

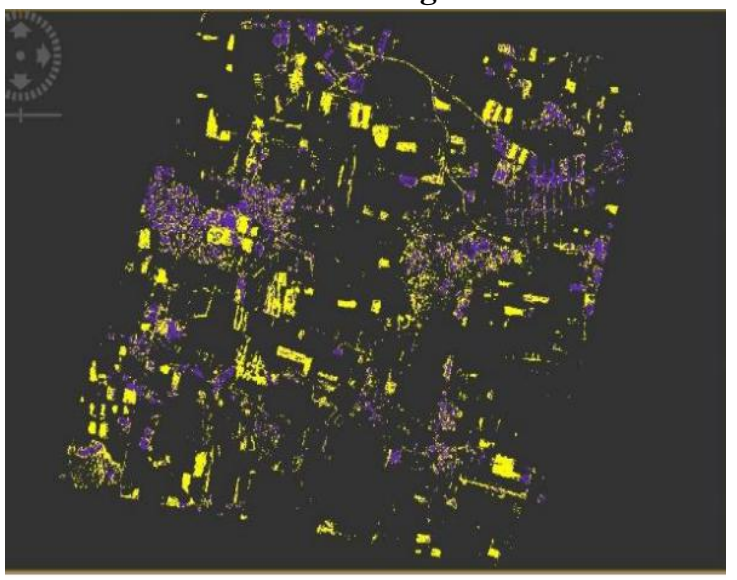

Fig. 13 Classification of Poultry Farms and other buildings

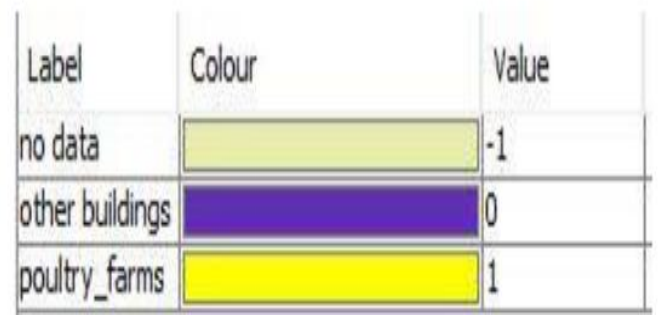

Fig. 14 Classes and their colour mapping

\section{ANALYSIS}

A. Accuracy of Poultry Farms by comparision of area

Table II : Comparision of the Two Pixel Based Classification Methods
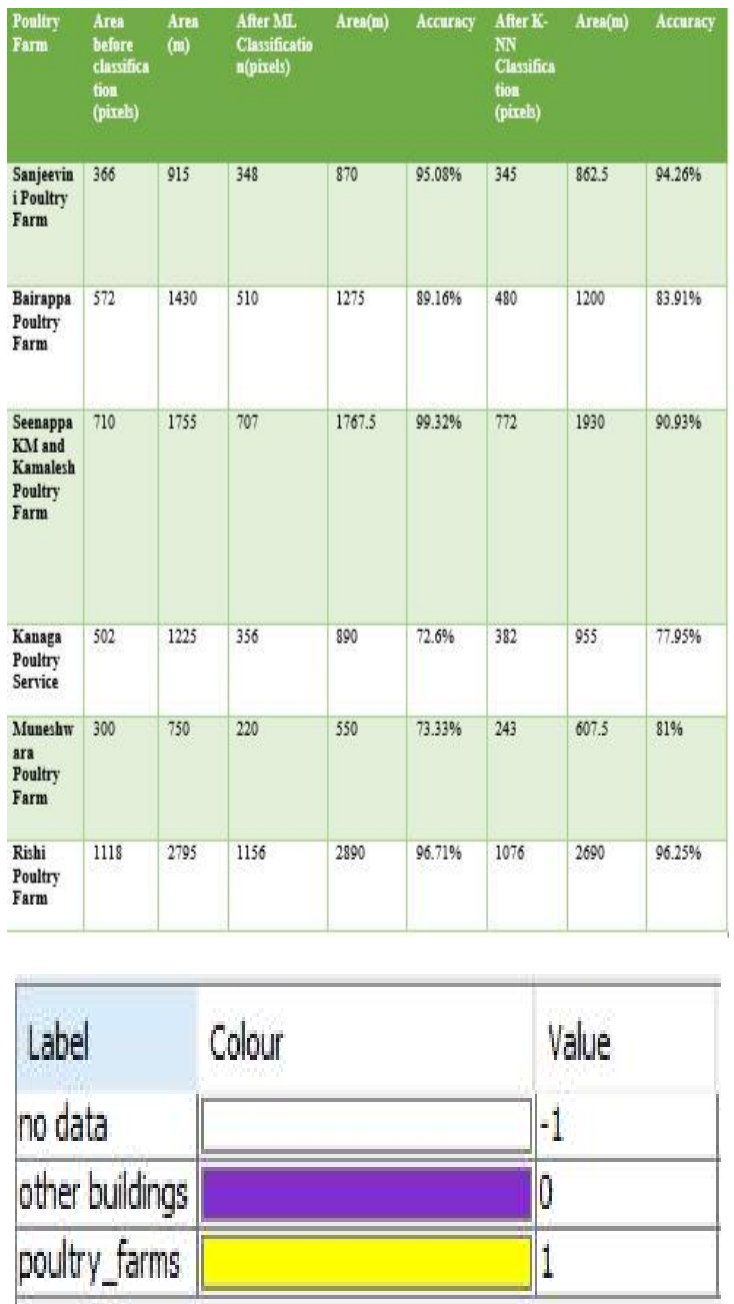

Fig 12. Classes and their colour map

2)K-Nearest Neighbour Classifier:

The K-NN Classifier Output highlighted the poultry farms in yellow, and represented the "other buildings" class in purple as shown in Fig. 13 and Fig. 14.

Calculating from Table II,

Average Accuracy of ML Classifier $=\mathbf{8 7 . 6 9 5} \%$

Average Accuracy of K-NN Classifier $=87.3 \%$

Therefore, Maximum Likelihood Classifier is the ideal Classification Method.

\section{B. Accuracy assessment using Confusion Matrix}

A confusion matrix is a table that shows correspondence between the classification result

and a reference image. From the confusion matrix, Kappa (Cohen) coefficient was derived. The kappa coefficient reflects the difference between actual agreement and the agreement by chance.

$\mathrm{K}$ (Kappa Coefficient $)=$

Observed Agreement - Chance

Agreement

\section{1-Chance Agreement}

1) K Nearest Neighbour Classifier: 
Table III: Confusion Matrix for KNN

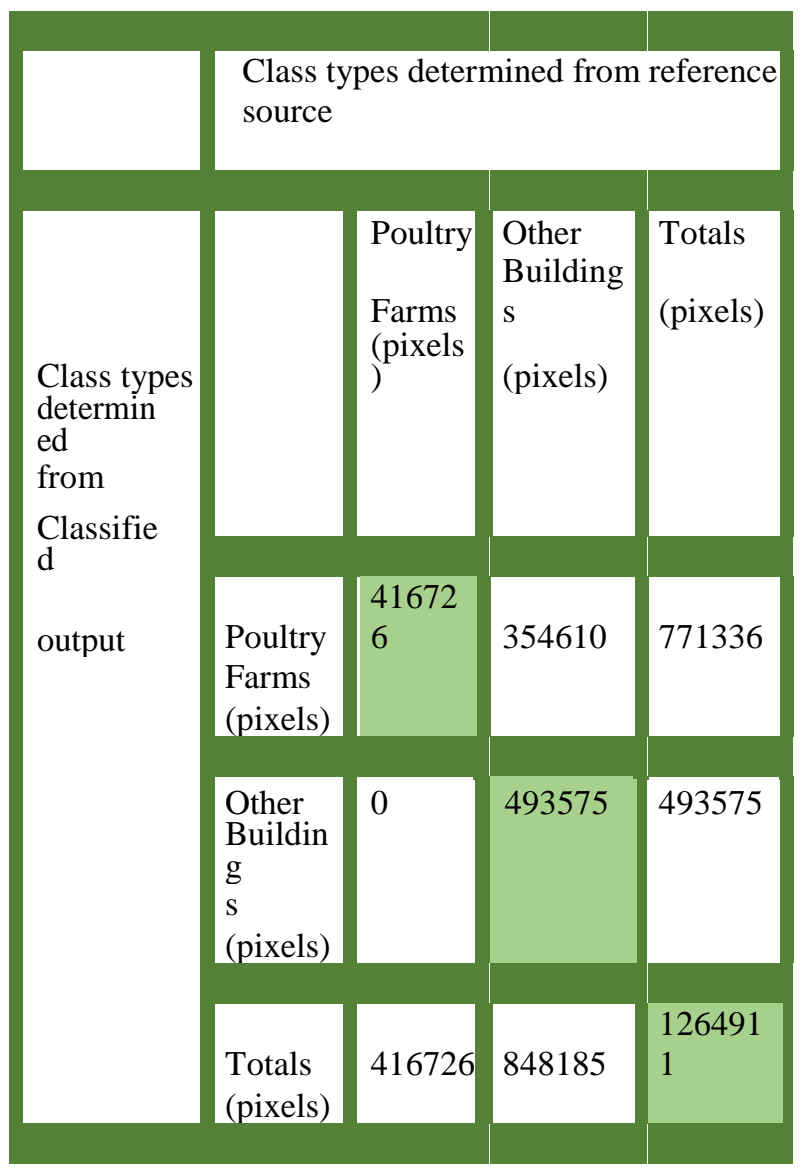

Accuracy Total $($ Observed Accuracy $)=$ $\sum$
$=(416726+493575) / 1264911=0.71965$

Chance Agreement =

$((416726 / 1264911) *(771336 / 1264911))+((848185 /$

$1264911) *(493575 / 1264911))=0.4625$

K $($ Kappa Coefficient $)=(0.71965-0.4625) /(1-$

$0.4625)=0.478$

2) Maximum Likelihood Classifier:

Table IV: Confusion Matrix for ML

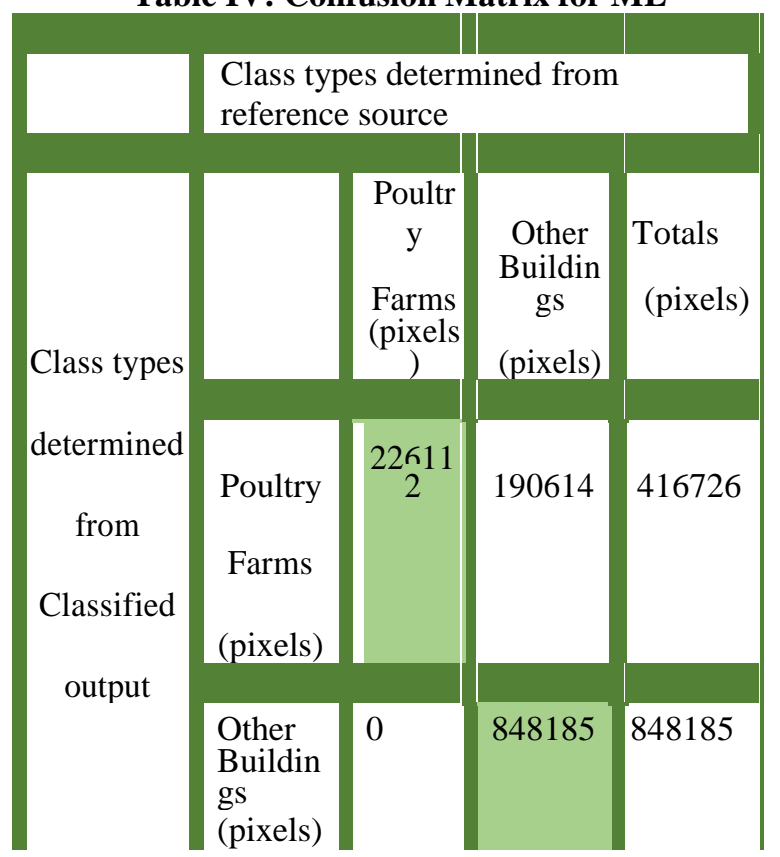

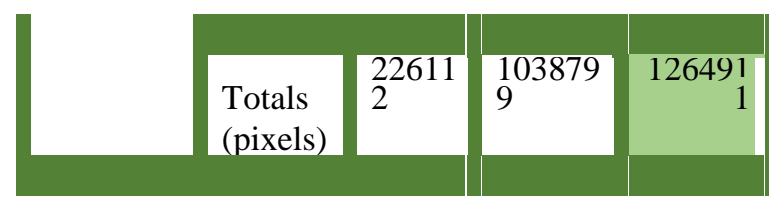

Accuracy Total (Observed Accuracy) $=$

$(226112+848185) / 1264911=0.84930$

Chance Agreement $=((226112 / 1264911)$

$*(416726 / 1264911))+((1038799 / 1264911) *($

$848185 / 1264911))=0.6095$

K $($ Kappa Coefficient $)=0.84930-0.6095 /(1-0.6095)$

$=0.614$

Kappa Coefficient in the range $.40-0.59$ is considered to be weak whereas that in the range .60 to .79 is considered to be of moderate strength. Hence, it can be concluded that Maximum Likelihood is the more accurate supervised classification method.

\section{CONCLUSION AND FUTURE SCOPE}

Under this project, from the satellite data (CARTOSAT, RESOURCEST-LISS4 and Google Earth), using SNAP software, vector data sets were created, and applied on the .tiff file. Water and vegetation masks were created by calculating NDVI and buildings and poultry farms were extracted. And then, two supervised pixel-based classification methods - Maximum Likelihood Classifier and K-Nearest Neighbour Classifier were applied. Statistics were used for analysis of the ideal classification method. The analysis from Table II and comparison of the Kappa Coefficients calculated from Table III and IV, showed that Maximum Likelihood Classifier gives better accuracy.

The study showed that Satellite images can be used for identifying Poultry Farms with high accuracy. This will help in making an inventory of Poultry Farms in the country. The project can be further extended for automatic identification of the poultry farms. The .tiff files (data sets) can be trained by creating various vector sets, and classifying them. Another approach would be to use object-based segmentation instead of pixel-based classification.

\section{REFERENCES}

1. Poultry Farm and Manual Reference guide for central and state poultry farms 2014-15" document released by Department of Animal Husbandry.

2. Facilitator Guide- Small Poultry Farmer" by Agriculture Skill Council of India

3. http://agritech.tnau.ac.in/expert_system/poultry/ Poultry\%20House\%20Construction.html

4. https://homepages.inf.ed.ac.uk/rbf/HIPR2/erode. htm

5. SNAP - ESA Sentinel Application Platform v2.0.2, http://step.esa.int
Published By:

6 Blue Eyes Intelligence Engineering \& Sciences Publication 